\title{
Distribution and sources of mercury in soils from former industrialized urban areas of Beijing, China
}

\author{
Wei Luo • Yonglong Lu • Bin Wang • \\ Xiaojuan Tong • Guang Wang • Yajuan Shi • \\ Tieyu Wang • John P. Giesy
}

Received: 11 June 2008 / Accepted: 29 September 2008 / Published online: 30 October 2008

(C) Springer Science + Business Media B.V. 2008

\begin{abstract}
Fifty-seven typical surface soils and 108 deeper soils were collected from five former industrial sites in Beijing and concentrations of
\end{abstract}

\footnotetext{
W. Luo · Y. Lu ( $\varangle) \cdot$ B. Wang · G. Wang .

Y. Shi - T. Wang

State Key Lab of Urban and Regional Ecology,

Research Center for Eco-Environmental Sciences, Chinese Academy of Sciences, Beijing 100085, China

e-mail: yllu@rcees.ac.cn

X. Tong

College of Forestry, Beijing Forestry University,

Beijing 100083, China

J. P. Giesy

Department of Veterinary Biomedical Sciences and

Toxicology Centre, University of Saskatchewan,

Saskatoon, Saskatchewan, Canada

J. P. Giesy

Zoology Department, National Food Safety and

Toxicology Center and Center for Integrative

Toxicology, Michigan State University,

East Lansing, MI 48824, USA

J. P. Giesy

Centre for Coastal Pollution and Conservation,

Department of Biology and Chemistry,

City University of Hong Kong, Tat Chee Avenue,

Kowloon, Hong Kong SAR, China

J. P. Giesy

Environmental Science Program,

Nanjing University, Nanjing, China
}

total $\mathrm{Hg}(\Sigma \mathrm{Hg})$ as well as $\mathrm{pH}$, total carbon (TC), total nitrogen $(\mathrm{TN})$, total sulfur, and dissolved organic carbon concentrations determined. The mean concentration of $\Sigma \mathrm{Hg}$ in surface soils was significantly greater than background concentrations in the vicinity of Beijing. Forty-eight percent of the samples exceeded the "critical" concentration of $1.0 \mathrm{mg} \mathrm{Hg} / \mathrm{kg}$, dry weight in soils, which has been established by the Chinese government. At depths of $0-80 \mathrm{~cm}$ in the soil, profile concentrations of $\Sigma \mathrm{Hg}$ also exceeded the background value. There were significant correlations between concentrations of $\Sigma \mathrm{Hg}$, TC, and $\mathrm{TN}$ in the industrial soils. The greater concentration of $\Sigma \mathrm{Hg}$ in most soils could have been due in part to combustion of coal and leakage from industrial processes.

Keywords $\mathrm{Hg} \cdot$ Metal $\cdot$ Pollution • Contamination

\section{Introduction}

Mercury $(\mathrm{Hg})$ is one of the most toxic elements and can cause renal and neurotoxicity to humans and wildlife. It has been identified as a priority toxic substance in many countries (Gaudet et al. 1995). The amount of $\mathrm{Hg}$ mobilized and released into the environment has increased since the beginning of the industrial age (Mason et al. 1994). 
However, $\mathrm{Hg}$ contamination and its effects upon the environment and human beings were only recognized as a significant environmental issue after the tragic accident that occurred in the Bay of Miuamata, Japan in 1956. Because of Hg's volatility and toxicity, it is recognized as a global environmental problem by scientists and the general public (Agamuthu and Mahalingam 2005).

$\mathrm{Hg}$ pollution is primarily due to human activities. Emissions of $\mathrm{Hg}$ from human activities accounted for $60 \%$ to $90 \%$ of the total $\mathrm{Hg}(\Sigma \mathrm{Hg})$ emitted in some industrialized regions (Nriagu 1989). Between 1990 and 1995, emissions of $\mathrm{Hg}$ due to human activities in Asia increased from approximately $30 \%$ of the total global emissions to $56 \%(1,074 / 1,912 \mathrm{t})$. Within that 5-year period, due to rapid industrialization, emissions in China alone increased by $250 \mathrm{t}$ (Pacyna and Pacyna 2001). Most of the world's industries are located in urban settings, and a large proportion of $\mathrm{Hg}$ emissions from industries are deposited locally (Landis et al. 2004). The greatest concentrations of $\Sigma \mathrm{Hg}$ in soils of industrialized areas were at least 20 -fold greater than background concentrations (Linde et al. 2001).

The industrialization of the Beijing began in the 1950s. The main industries included electronics, manufacturing, including what is classified as heavy industry, and chemical production. The number of industrial facilities eventually totaled about 20,000. With Beijing's successful application to host the Olympic Games in 2008 and the rapid extension of urban areas in recent years, most industrial plants in the city are being closed or moved from downtown to suburban areas. These former industrial sites have been converted into commercial and residential properties. It is increasingly being recognized that these industrial sites might have become significantly contaminated by these industrial activities to levels that might be significant risks to human health. Mercury pollution of soil is one potential environmental problem because $\mathrm{Hg}$ was contained in airborne fallout, waste dumping, liquid leakage and incidental emissions from the workshops, waste treatment plants, and storage locations of old equipment in the former industrial plants. It has been reported that there are relatively great concentrations of $\mathrm{Hg}$ not only in the air, snow
(Liu et al. 2002; Wang et al. 2004), and drinking water in the Beijing urban areas (Gao et al. 2004) but also in soils on the outskirts of Beijing (Tan et al. 2005). Soils of Beijing exposed to industrial sewage and sludge have been found to be contaminated with $\mathrm{Hg}$ (Zhu 2001). An investigation indicated that the concentration of $\mathrm{Hg}$ in people's hair was greater in industrial areas of Beijing (Wu et al. 1991). Communities built on such polluted sites can be at increased risk of environmental and human health problems, even long after the source of $\mathrm{Hg}$ has been discontinued. Therefore, it became important to determine potential sources of $\mathrm{Hg}$, including the distribution, and in soils at these former industrial sites and the potential exposure of urban inhabitants, especially children.

It is, however, rare to find information on $\mathrm{Hg}$ in soils from former industrialized areas of Beijing in the open literature. In order to ascertain the sources and distribution of $\mathrm{Hg}$, as well as the location and extent of contamination with $\mathrm{Hg}$, and to provide policymakers with remediation measures for the affected soils, a detailed study of surface soils and complete soil profiles was conducted in industrialized urban areas of Beijing. Concentrations of $\Sigma \mathrm{Hg}$ were measured in soils, and the profiles of $\Sigma \mathrm{Hg}$ concentrations were interpreted as a function of depth and their relationship with soil properties and possible sources in the former industrial sites discussed. The results obtained can be of use for the municipal land planners and managers to identify pollution sources, locate polluted areas for remediation measures, and to choose the proper cleanup strategies. Moreover, the data may be of interest to environmental agencies for their activities of soil monitoring.

\section{Materials and methods}

Site description

The industrialized urban area was located approximately 1-8 $\mathrm{km}$ southeast of the center of Beijing. Industrial activity in the area started in the 1950s and ended around 2006. Five representative industrial sites (denoted as A, B, C, D, and $\mathrm{E}$ ) in the industrialized area were studied. 
Plant A was established in 1958 and its main products were chemical agents, fluorescent, and photosensitive materials. Plant B was established in 1956 and produced pesticides, polyvinyl chloride plastic, and rubber products. Plant $\mathrm{C}$ was built in 1959 and its main products were coke, coal gas, ammonium sulfate, benzene, naphthalene, and hydroxybenzene. Plants D and E were established, respectively, in 1954 and 1956. Plant D mainly produced pesticides, lacquer, and building and industrial paint, while Plant E mainly produced dyestuffs, paint products, and vitriol. All of the plants have now been closed or moved, and some residential communities have been, or will be, established on the land. There are also other facilities in the area, such as hospitals, schools, residential communities, restaurants, and guesthouses. The soils in the investigated area developed on a sandy-textured alluvial deposit and are dominated by silt and sandy loams; the predominant soil types are typically fluvial in origin. Sampling locations taking up most of the site were selected based on locations of production and waste treatment sectors, which were potentially important sources of contamination.

\section{Sample collection}

Fifty-seven representative surface soils and 108 deep layer soil samples from 27 profile pits were collected from the five sites (Fig. 1). Four subsamples were collected at each sampling point and mixed thoroughly to get a representative soil sample. The deeper samples of soil were taken from each profile pit at depths of 20,80, 180, or $400 \mathrm{~cm}$.

\section{Soil analysis}

Prior to analysis, soil samples were air-dried, crushed in an agate mortar, and passed through a nylon sieve of $0.149 \mathrm{~mm}$. For total $\mathrm{Hg}$ analysis, $0.2-0.3 \mathrm{~g}$ dry soil samples were digested at $95^{\circ} \mathrm{C}$ in a water bath with an acid mixture of $\mathrm{HCl}$ / $\mathrm{HNO}_{3}$. Mercury concentrations were measured in digested sample solution by use of cold-vapor atomic absorption spectrometry, with the instrument detection limit of $0.01 \mu \mathrm{g} \mathrm{Hg} / \mathrm{kg}$, wet weight. A standard soil sample GBW-07405 (GSS-5)
$0.29 \pm 0.04 \mathrm{mg} \mathrm{Hg} / \mathrm{kg}$ dry weight $(\mathrm{dw})$, from the Center of National Standard Reference Material of China, was used to evaluate the analytical accuracy within $5 \%$. The concentration measured was $0.30 \pm 0.01 \mathrm{mg} \mathrm{Hg} / \mathrm{kg}$, dw, with the average recovery rate of $103 \%$ in triplicate analysis. Precision was estimated by use of analysis of duplicate. The precision was greater than $95 \%$.

Fifteen grams of sample was dissolved in $15 \mathrm{ml}$ of deionized water, and after mixing for $24 \mathrm{~h}$, the $\mathrm{pH}$ was measured. For dissolved organic carbon (DOC) measurements, $7 \mathrm{~g}$ of soil was shaken with $28 \mathrm{ml}$ of distilled water for $1 \mathrm{~h}$, followed by centrifugation and filtration through $0.45-\mu \mathrm{m}$ filters (Wright et al. 2005). Extracts were analyzed for DOC by persulfate oxidation using a total organic carbon analyzer (model 7000, OI Corporation, TX, USA). Concentrations of total carbon (TC), total nitrogen (TN), and total sulfur (TS) were determined by use of a Universal CHNOS elemental analyzer (Elementar Vario EL III, Germany; Mai et al. 2003).

\section{Statistical treatment}

Statistical analyses were carried out using Microsoft Excel and SPSS 10.01 software (SPSS Inc., USA). The normal distribution of $\mathrm{Hg}$ concentrations was tested by the Kolmogorov-Smirnov method. Analyses of significant differences of $\mathrm{Hg}$ concentrations between two sites were performed by the analysis of variance (data with normal distribution) or by the Kruskal-Wallis $H$ test (non-parametric data). A significance level of $P<0.05$ was used throughout the study. Relationships between parameters were investigated by use of Spearman rank-order correlation (nonparametric data) or Pearson product-moment correlation (normal distribution).

\section{Results and discussion}

Total concentrations of mercury in surface soils

Concentrations of $\mathrm{Hg}$ in soils were plotted as histograms and normal probability plots either arithmetically (Fig. 2) or after logarithmic transformation (Fig. 3). Skewness or kurtosis indicates 


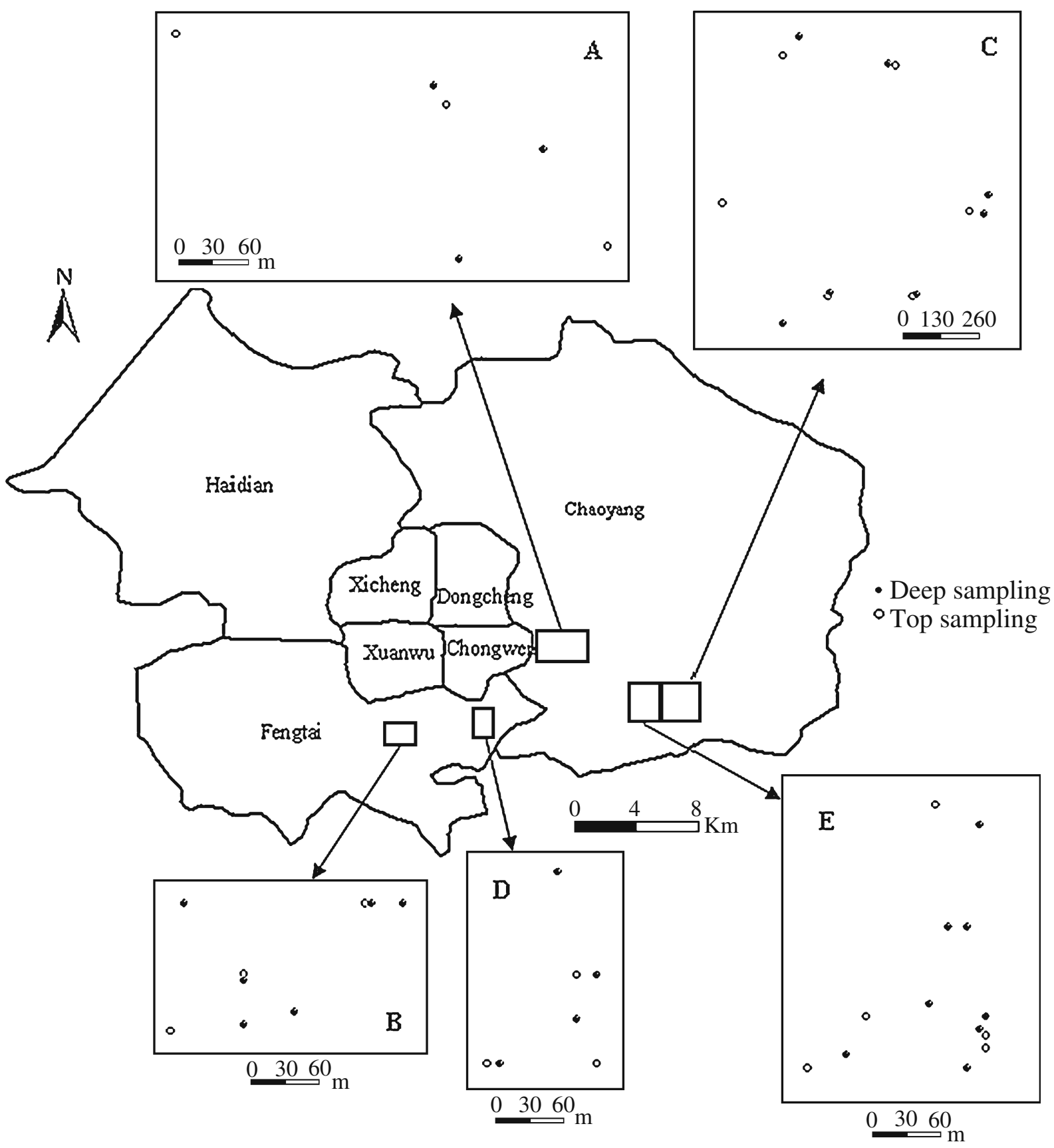

Fig. 1 Map of sampling locations in the industrialized urban areas of Beijing, China

departures from normality. The normal probability plot provides a visual estimate of the nearness of the data to a normal distribution. If the data are normally distributed, their points will fall on a straight line in such a plot, and curvature in the points indicates a deviation from a normal distribution. Thus, the distribution of $\Sigma \mathrm{Hg}$ in the surface soil samples was lognormal (Figs. 2 and 3).

Bare soil on the ground surface may serve as local "hot spots" for $\mathrm{Hg}$ emissions because of the large percentage of $\Sigma \mathrm{Hg}$ lying in the upper few centimeters of soil. The mean concentration 

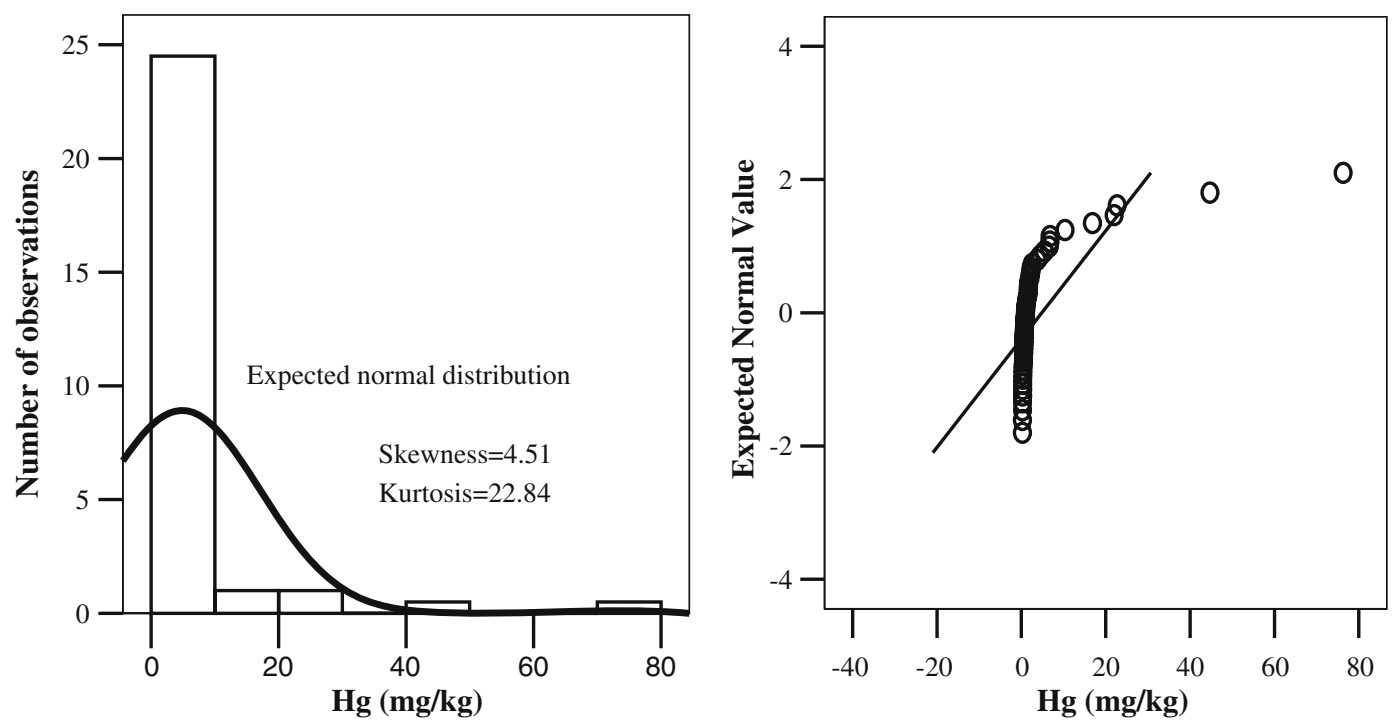

Fig. 2 Histogram and normal probability graph of $\Sigma \mathrm{Hg}$ concentrations in surface soil samples

of $\Sigma \mathrm{Hg}(4.85 \mathrm{mg} \mathrm{Hg} / \mathrm{kg}, \mathrm{dw})$ in the Beijing industrial soils (Table 1) was significantly greater than the background concentration of $\Sigma \mathrm{Hg}$ in other Beijing soils (0.06 mg Hg/kg, dw; CNEMC 1990), as well as the Beijing urban soil background concentration $(0.28 \mathrm{mg} \mathrm{Hg} / \mathrm{kg}$, dw; Zhang et al. 2006). According to the guidelines for $\mathrm{Hg}(\mathrm{Wu}$ and Zhou 1991), 100\% of the soil samples from Beijing industrial sites exceeded the "ideal" con- centration $(0.1 \mathrm{mg} \mathrm{Hg} / \mathrm{kg}, \mathrm{dw})$ and "acceptable" concentration or "threshold" value $(0.2 \mathrm{mg} \mathrm{Hg} / \mathrm{kg}$, $\mathrm{dw}$ ), which indicates that very careful environmental management is necessary. Seventy-seven percent of the soil samples exceeded the "tolerable" concentration, which also corresponds to the "warning" value $(0.5 \mathrm{mg} \mathrm{Hg} / \mathrm{kg}$, dw $)$. This means that $77 \%$ of the area is only mildly ecologically impacted, and the foodstuff grown on this area
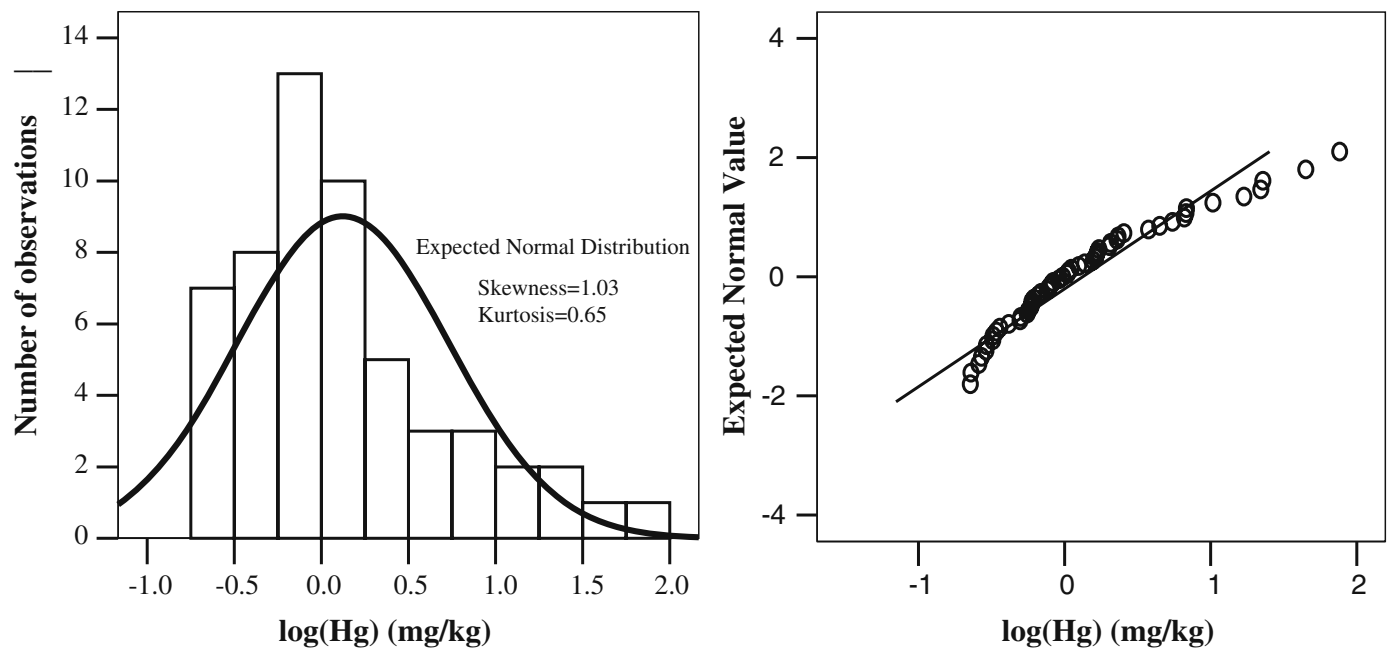

Fig. 3 Histogram and normal probability graph of $\Sigma \mathrm{Hg}$ concentrations in surface soil samples after $\log _{10}$ transformation of the data 


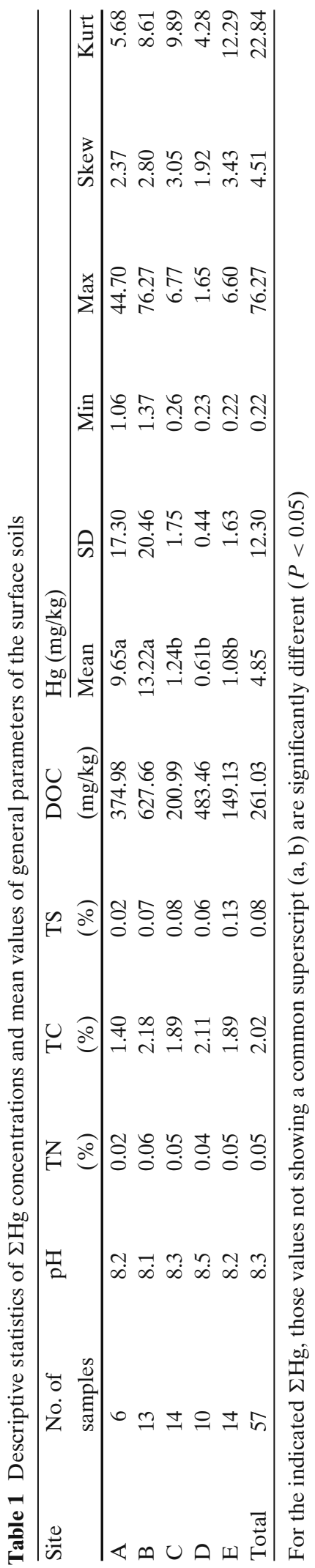

had elevated concentrations of $\mathrm{Hg}$. Forty-eight percent of the soil samples exceeded the "critical" concentration $(1.0 \mathrm{mg} \mathrm{Hg} / \mathrm{kg}, \mathrm{dw})$, which means that $48 \%$ of the area is affected by anthropogenic input of $\Sigma \mathrm{Hg}$. Due to the chemical and physical nature of surfaces of the plants in the area, their large spatial variability, the time series characteristics of industrial $\mathrm{Hg}$ emissions (i.e., industrial burning, processing, waste incineration; Liu et al. 2002; Feng et al. 2003), the ambient Hg concentrations, and the urban meteorology, the $\Sigma \mathrm{Hg}$ concentrations in the soils of the industrialized urban land was significantly greater than those of farmland (Table 2). This result is in agreement with the results of another study (Hollis 1991). Furthermore, based on the soil cleanup standards (SCS) for $\mathrm{Hg}$ in soils used for residential or industrial purposes in some countries (Table 3), only two samples contained concentrations of $\Sigma \mathrm{Hg}$ greater than the USA residential SCS, four samples were greater than the German SCS, and five were greater than the SCS from Belgium. However, based on the standards of other countries, 50 samples $(89 \%)$ contained concentrations that were less than $8.0 \mathrm{mg} \mathrm{Hg} / \mathrm{kg}$, dw, which implies that $89 \%$ of the industrialized urban land can be used for residential purposes. According to the soil cleanup standards for $\mathrm{Hg}$ for industrial land use in most countries, most industrialized urban land (except one or two places) in Beijing can continue to be used for industrial purposes.

Because none of the distributions of $\mathrm{Hg}$ concentrations in soils was normally distributed based on skewness and kurtosis (Table 1), the KruskalWallis test, a method used for non-normal data distributions, was used to test for differences between the means of the $\mathrm{Hg}$ concentrations in the surface soil samples of different sites. Mean $\mathrm{Hg}$

Table 2 Comparison of $\Sigma \mathrm{Hg}$ concentrations (mg $\Sigma \mathrm{Hg} / \mathrm{kg}$, $\mathrm{dw}$ ) in industrial soils with those in farmland soils in Beijing

\begin{tabular}{lllrrr}
\hline & $N$ & Mean & \multicolumn{1}{c}{ SD } & Min & Max \\
\hline Farm land $^{\mathrm{a}}$ & 45 & 0.04 & 0.03 & 0.01 & 0.16 \\
Industrial land $^{\text {Background value }}{ }^{\mathrm{b}}$ & 38 & 4.85 & 12.30 & 0.22 & 76.27 \\
Back $^{2}$ & 0.06 & 0.08 & 0.00 & 45.90 \\
\hline${ }^{\mathrm{a}}$ Li et al. (2006) & & & & & \\
${ }^{\mathrm{b}}$ CNEMC (1990) & & & & &
\end{tabular}


Table 3 Overview of the soil cleanup standards for $\Sigma \mathrm{Hg}$ $(\mathrm{mg} / \mathrm{kg}, \mathrm{dw})$ for residential and industrial land uses in various countries (Provoost et al. 2006)

\begin{tabular}{llc}
\hline Country & Residential land & Industrial land \\
\hline Belgium & 15 & 30 \\
Germany & 20 & 80 \\
France & 7 & 600 \\
Sweden & 1 & 7 \\
Great Britain & 8 & 480 \\
Canada & 6.6 & 50 \\
USA & 23 & 310 \\
\hline
\end{tabular}

concentrations of soils were the following decreasing order: $\mathrm{B}>\mathrm{A}>\mathrm{C}>\mathrm{E}>\mathrm{D}$. Mean $\mathrm{Hg}$ concentrations in soils of sites B $(13.22 \mathrm{mg} \mathrm{Hg} / \mathrm{kg}$, $\mathrm{dw})$ and $\mathrm{A}(9.7 \mathrm{mg} \mathrm{Hg} / \mathrm{kg}, \mathrm{dw})$ were significantly greater than any other site $(P<0.05)$. This indicates that the surface soils in areas of industries like those at Plants B and A may have the greatest $\mathrm{Hg}$ pollution potential.

Total mercury concentrations in soil profiles

There was no statistically significant difference in mean $\Sigma \mathrm{Hg}$ concentrations between samples taken at $20-$ or $80-\mathrm{cm}$ depths as a whole (Table 4). However, the mean concentrations of $\Sigma \mathrm{Hg}$ at these depths were significantly greater than those at depths of 180 and $400 \mathrm{~cm}$. At depths of 20 or $80 \mathrm{~cm}$, there were six soils (three at $20 \mathrm{~cm}$ and three at $80 \mathrm{~cm}$ ) whose $\mathrm{Hg}$ concentrations were greater than the maximum soil cleanup standard for $\mathrm{Hg}$ for residential areas (Table 3). No soil sample from depths of 180 and $400 \mathrm{~cm}$ had a $\Sigma \mathrm{Hg}$ concentration greater than $6.6 \mathrm{mg} \mathrm{Hg} / \mathrm{kg}$, dw (Fig. 4). Although these five plants had almost the

Table 4 Descriptive statistics of mercury concentrations at different soil depths in the industrial area $(\mathrm{mg} \Sigma \mathrm{Hg} /$ $\mathrm{kg}, \mathrm{dw})$

\begin{tabular}{lllllr}
\hline Depth $(\mathrm{cm})$ & $\begin{array}{l}\text { Number of } \\
\text { samples }\end{array}$ & Mean $^{\mathrm{a}}$ & SD & Min & Max \\
\hline 20 & 27 & $3.64 \mathrm{a}$ & 6.27 & 0.22 & 22.72 \\
80 & 27 & $3.65 \mathrm{a}$ & 7.00 & 0.01 & 29.66 \\
180 & 27 & $0.98 \mathrm{~b}$ & 1.52 & 0.05 & 6.31 \\
400 & 27 & $1.11 \mathrm{~b}$ & 1.36 & 0.08 & 4.25 \\
\hline
\end{tabular}

${ }^{\mathrm{a}}$ For the indicated elements, those values not showing a common superscript $(\mathrm{a}, \mathrm{b})$ are significantly different at the level $(P<0.05)$

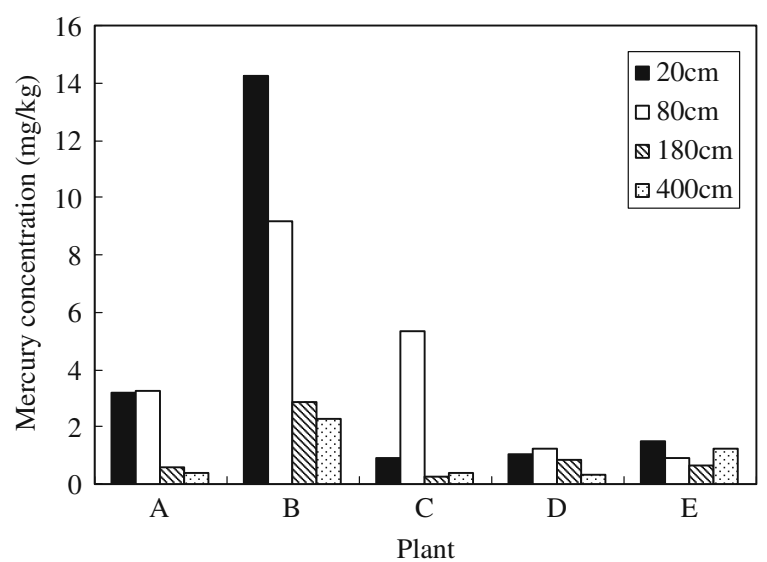

Fig. 4 Mercury $(\Sigma \mathrm{Hg})$ concentration profiles with depth at different industrial sites

same periods of production, they had different distributions of $\Sigma \mathrm{Hg}$ concentration in the deep soils. Soils from site $\mathrm{B}$ contained the greatest mean concentration of $\Sigma \mathrm{Hg}$ in the profile. For profiles in which the maximum $\Sigma \mathrm{Hg}$ content was found to lie between 20 and $80 \mathrm{~cm}$, three possible causes are possible. First, Hg could have leached downward by colloidal transport (Jacobsen et al. 1998). Second, $\mathrm{Hg}$ could have evaporated from the surface soil (Schlúter 2000) as either methyl mercury or elemental mercury $\mathrm{Hg}^{\circ}$, but the degree to which $\mathrm{Hg}^{\circ}$ evaporates is small. Nater and Grigal (1992) indicated that soils retain about $90 \%$ of the $\Sigma \mathrm{Hg}$ deposited on them. Similar findings were observed in other studies and it was found that in spite of the evaporation of $\mathrm{Hg}^{\circ}$, there is a net accumulation of $\mathrm{Hg}$ in soils (Mason et al. 1994). Finally, plants may have absorbed $\mathrm{Hg}$ from the soil. All three of these possibilities most likely have contributed to decreasing the concentrations of $\Sigma \mathrm{Hg}$ in the upper soils. Of these possibilities, colloidal transport appears to be the most likely mechanism for decreasing the $\Sigma \mathrm{Hg}$ concentration in the upper soils. Since maximum mean $\Sigma \mathrm{Hg}$ concentrations were observed at a depth of $80 \mathrm{~cm}$, some remedial actions should be taken to remove the soils in the depth range of $0-80 \mathrm{~cm}$. The economic aspects of remediation are usually not easily accessible, although they generally determine whether a remediation project will be executed or not. Based on the study by Hylander and Goodsite (2006), remediation costs range between US $\$ 2,500$ and 
US \$1.1 million per kilogram $\mathrm{Hg}$ isolated from the biosphere depending on local circumstances such as quantities to secure, nature of pollution, media, geography, technology chosen, etc. The remediation technologies are expensive and complex processes, mostly effective at very high mercury concentrations. Remediation technologies appropriate for mercury removal include liquid extraction, thermal treatment, electrolytic methods, mercury flotation, or immobilization. Among them, phytoremediation may provide an efficient and practical cost-effective solution to mercury contamination (Sas-Nowosielska et al. 2008).

\section{Soil properties and mercury concentrations}

To investigate the common characteristics (behavior, origin, etc.) of $\Sigma \mathrm{Hg}$ in soils in the urban areas of Beijing, correlation coefficients (Pearson product-moment coefficients) between mercury and the soil properties were calculated. Organic matter in soil is known to play a role in adsorption of $\mathrm{Hg}$ (Semu et al. 1987), although its quantitative contribution is not clearly understood. In this study, there was a positive correlation between TC and $\Sigma \mathrm{Hg}$ concentration (Table 5). This result is in agreement with the results of Semu and Singh (1987). Surface soils, rich in organic matter, adsorb significantly greater amounts of $\mathrm{Hg}$ (Trost and Bisque 1972) and create strong organic complexes of great stability (Shuster 1991). Due to the affinity of $\mathrm{Hg}$ for organic matter, soil $\mathrm{Hg}$ leaching rates should be small because the industrialized urban soils in Beijing have great concentrations of organic matter $(2.02 \%$; Table 1$)$. Furthermore, the results of Landa (1978) sug-

Table 5 Rank correlation coefficients for $\Sigma \mathrm{Hg}$ and chemical properties in the soils $(n=57)$ from the Beijing industrialized urban area

\begin{tabular}{lcrlllll}
\hline & $\mathrm{Hg}$ & $\mathrm{pH}$ & $\mathrm{TN}$ & $\mathrm{TC}$ & $\mathrm{TS}$ & $\mathrm{C} / \mathrm{N}$ & $\mathrm{DOC}$ \\
\hline $\mathrm{Hg}$ & 1.00 & & & & & & \\
$\mathrm{pH}$ & -0.12 & 1.00 & & & & & \\
$\mathrm{TN}$ & $0.35^{* *}$ & -0.11 & 1.00 & & & & \\
$\mathrm{TC}$ & $0.35^{* *}$ & 0.05 & $0.68^{* *}$ & 1.00 & & & \\
$\mathrm{TS}$ & 0.17 & -0.12 & $0.67^{* *}$ & $0.53^{* *}$ & 1.00 & & \\
$\mathrm{C} / \mathrm{N}$ & 0.06 & 0.15 & $-0.44^{* *}$ & 0.25 & $-0.27^{* *}$ & 1.00 \\
$\mathrm{DOC}$ & 0.23 & 0.12 & $0.44^{* *}$ & $0.50^{* *}$ & $0.52^{* *}$ & -0.27 & 1.00 \\
\hline
\end{tabular}

** Correlation is significant at the 0.01 level (two-tailed) gested that in addition to quantity, the nature of a soils' organic matter also influences adsorption of $\mathrm{Hg}$. It is important to pay close attention to DOC because of its large influence on sorption of $\mathrm{Hg}$ (Reddy and Aiken 2001). However, there was no significant correlation between $\Sigma \mathrm{Hg}$ concentration and dissolved organic carbon in our study (Table 5), which is not in agreement with results reported in other studies (Shuster 1991; Linde et al. 2007). Further study is needed to explain this. Changes in $\mathrm{pH}$ can also have a major effect on a soil's ability to retain $\mathrm{Hg}$. Mercury adsorption generally decreases with decreasing $\mathrm{pH}$ due to $\mathrm{H}^{+}$ions removing and replacing $\mathrm{Hg}$ ions. However, in our study, all samples were slightly alkaline, with a mean $\mathrm{pH}$ value of 8.2 (Table 1), and there was no significant correlation between soil $\mathrm{pH}$ and $\mathrm{\Sigma Hg}$ concentration (Table 5). This means that adsorption of $\mathrm{Hg}$ by soils would not change when the soil is in alkaline. Furthermore, concentrations of $\mathrm{Hg}$ were significantly correlated with concentrations of $\mathrm{TN}$, but not $\mathrm{C} / \mathrm{N}$ ratio or $\mathrm{TS}$ (Table 5). $\mathrm{C} / \mathrm{N}$ ratio is often related to humification (Gobat et al. 1998). In this study, high organic $\mathrm{C} / \mathrm{N}$ ratios ( $>36)$ is characteristic of a low humification state of organic matter and of poor bacterial activity (Semu et al. 1987; Gobat et al. 1998). Little humification of organic matter and of poor bacterial activity may have resulted in relatively little complexation of $\mathrm{Hg}$. Therefore, the $\mathrm{C} / \mathrm{N}$ ratio was poorly correlated with $\mathrm{Hg}$. In relatively more-reducing environments, $\mathrm{Hg}$ appears to be converted, in large part, to relatively insoluble HgS (Lechler et al. 1997). However, in this study, due to the small concentration of TC (about $2 \%$ ) in soils of industrial sites and great oxygenation and oxidant-to-reducing environmental conditions at the surface soils, $\mathrm{HgS}$ may have become soluble (Moore and Ramamoorthy 1984). This may be the reason for the poor correlation between $\mathrm{Hg}$ and TS in the soils. Significant relationships between $\Sigma \mathrm{Hg}$ concentrations and TC and TN suggest that organic matter and nitrogen in the soils control $\Sigma \mathrm{Hg}$ concentrations of industrial urban soils and that adsorption and retention of $\Sigma \mathrm{Hg}$ in these industrial soils is influenced by organic matter and nitrogen. Thus, organic matter and nitrogen may be important sinks for $\Sigma \mathrm{Hg}$ in the soils studied. 
Source of mercury

Industrialized urban areas are complex systems in which human activities have disturbed the natural development of soils. The possible inputs of $\mathrm{Hg}$ from industrial activities to urban lands include emissions from coal-burning power plants, residential or industrial boilers, waste incinerators, cement and lime kilns, petroleum refineries, landfills, fly ash from coal-burning locomotives, sewage sludge, and other sources. Mercury is also released during the life cycle of industrial products such as fluorescent lamps, electrical switches (electronics industry), thermostats, pressure sensing devices, products of chlorine-alkaline industry, paints, products of the paper industry, and products of the pharmaceutical industry (Sznopek and Goonan 2000). Based on our investigation, Plants A and B produced mercuric salts and phenylmercury acetate, respectively, but the other plants did not produce any $\mathrm{Hg}$-containing products. Therefore, the soil at sites $\mathrm{A}$ and $\mathrm{B}$ had relatively great concentrations of $\Sigma \mathrm{Hg}$ (Table 1 and Fig. 3). We concluded that the processes of producing $\mathrm{Hg}$-containing products likely resulted in contamination of soils with $\mathrm{Hg}$ at these Beijing industrial sites. However, since industrial boilers, combustors, or incinerators relied heavily on coal for energy in industrial processes, the relatively great concentrations of $\Sigma \mathrm{Hg}$ in soils from former industrialized urban areas of Beijing likely came primarily from industrial combustion of coal. The range of concentrations of $\mathrm{HG}$ in coal has been reported to be 0.1 to $0.56 \mathrm{mg} \mathrm{Hg} / \mathrm{kg}$ ( $\mathrm{Li} 1992$ ). Furthermore, soils with relatively great concentrations of $\Sigma \mathrm{Hg}$ also contained relatively great concentrations of $\mathrm{SO}_{2}$ from burning high-sulfur coal (Gao 1987). This indirectly indicates that $\mathrm{Hg}$ pollution in the soils studied may have come from coal combustion. Concentrations of $\Sigma \mathrm{Hg}$ in surface soils in the vicinity of plants $\mathrm{A}$ and $\mathrm{C}$ were 1.7 and $0.51 \mathrm{mg} \mathrm{Hg} / \mathrm{kg}$, dw, respectively. This was most likely due solely as a result of burning coal (Liu et al. 1997). Beyond emissions of $\mathrm{Hg}$ from industries, residential coal burning in winter could be another factor contributing to $\mathrm{Hg}$ pollution in the industrial soils. The average $\mathrm{Hg}$ concentration in coal used by Beijing residents is $0.3 \mathrm{mg} \Sigma \mathrm{Hg} /$ $\mathrm{kg}$, which is greater than the average concentra- tion in coal of China $(0.2 \mathrm{mg} \Sigma \mathrm{Hg} / \mathrm{kg}$; Jiang et al. 2005). Although $\Sigma \mathrm{Hg}$ concentrations in surface soils decreased gradually from the boundary of Beijing industrial plants to residential areas, the values in residential areas were still as great as 0.2-1.0 mg Hg/kg, dw. Atmospheric $\mathrm{Hg}$ can be deposited into the terrestrial ecosystem through dry and wet precipitation, which increases the concentrations of mercury in soils. Atmospheric mercury concentrations in urban Beijing were reported to be $10-13 \mathrm{ng} \Sigma \mathrm{Hg} / \mathrm{m}^{3}$ in summer and 8.3-25 $\mathrm{ng} \Sigma \mathrm{Hg} / \mathrm{m}^{3}$ in winter, respectively (Liu et al. 2002), which are several times greater than the global background range (1-3 ng $\Sigma \mathrm{Hg} / \mathrm{m}^{3}$; Tayban and Preston 2005). In addition, mercury concentrations in two snow samples from industrial areas of Beijing were 1.6 and $1.5 \mathrm{ng} \Sigma \mathrm{Hg} / \mathrm{l}$, respectively, which were greater than the background concentration of $\Sigma \mathrm{Hg}$ in wet precipitation (0.2 ng Hg/ml; Liu et al. 1997, 1998). Another source of $\mathrm{Hg}$ pollution is industrial leakage and runoff accidents. For example, the annual runoff of $\mathrm{Hg}$ from Plant A in 1977 was about $583 \mathrm{~kg}$ based on an investigation. Therefore, it was reported that there was a very great concentration of mercury in the soil profile from 0 - to $100-\mathrm{cm}$ depth in industrial areas as a result of leaching (Liu et al. 1998). Thus, the amount of $\mathrm{Hg}$ from leakage and runoff was one of the important factors that caused contamination of soils at Beijing industrial sites with $\mathrm{Hg}$.

\section{Conclusions}

The accumulation of $\Sigma \mathrm{Hg}$ in the surface soils is particularly obvious in industrialized urban lands in Beijing compared with the farmland. Concentrations of $\Sigma \mathrm{Hg}$ in $48 \%$ of surface soils in the industrial sites exceeded the "critical" concentration and were only mildly ecologically impacted as a result of the anthropogenic input. However, $89 \%$ of the industrialized urban land can be used for residential purposes. All the industrial surface soils need careful environmental management. Since $\mathrm{Hg}$ contamination was primarily confined to the top $0-80 \mathrm{~cm}$, some engineering measures should be taken to remove these soils. Organic matter and nitrogen may be important sinks for 
$\mathrm{Hg}$ in the industrial soils. The making processes of $\mathrm{Hg}$-containing products have caused heavy soil pollution of $\mathrm{Hg}$ at the industrial sites. Atmospheric $\mathrm{Hg}$ emitted by industrial and residential coal burning might have been the main cause of soil mercury contamination at most industrial sites in Beijing. Another source of $\mathrm{Hg}$ in industrial soils was industrial leakage and runoff.

Acknowledgements This research was supported by the National Basic Research Program (so-called 973 Research Program) with grant No.2007CB407307 and the Knowledge Innovation Program of the Chinese Academy of Sciences, with grant No.KZCX2-YW-420-5. Prof. Giesy was supported as an at large Chair Professorship from the Department of Biology and Chemistry and Research Centre for Coastal Pollution and Conservation, City University of Hong Kong and by an "Area of Excellence" Grant (AoE P-04/04) from the Hong Kong University Grants Committee.

\section{References}

Agamuthu, P., \& Mahalingam, R. (2005). Mercury emissions: Is there a global problem? Waste Management Research, 23, 485-486.

CNEMC (China National Environmental Monitoring Center) (1990). The background concentrations of soil elements in China. Beijing: China Environmental Science Press (in Chinese).

Feng, X., Tang, S., Shang, L., Yan, H., Sommar, J., \& Lindqvist, O. (2003). Total gaseous mercury in the atmosphere of Guiyang, PR China. Atmospheric Environment, 304, 61-72.

Gao, X. L. (1987). The distribution of mercury pollution in air in Beijing urban areas. Environmental Science, 8, 33-36 (in Chinese).

Gao, J. J., Zhang, L. P., Huang, S. B., Ma, M., \& Wang, Z. (2004). Preliminary health risk assessment of heavy metals in drinking waters in Beijing. Environmental Science, 25, 47-50 (in Chinese).

Gaudet, C., Lingard, S., Cureton, P., Keenleyside, K., Smithe, S., \& Raju, G. (1995). Canadian environmental quality guidelines for mercury. Water Air and Soil Pollution, 80, 1149-1159.

Gobat, J. M., Aragno, M., \& Matthey, W. (1998). The living soil. Bases of pedology. In Biology of soils. Lausanne: Polytechnic and Romandes University Presses (in French).

Hollis, J. M. (1991). The classification of soils in urban areas. Oxford: Blackwell.

Hylander, L. D., \& Goodsite, M. E. (2006). Environmental costs of mercury pollution. Science of the Total Environment, 368, 352-370.

Jacobsen, O. H., Moldrup, P., de Jonge, H., \& de Jonge, L. W. (1998). Mobilization and transport of natural colloids in a macroporous soil. Physics and Chemistry of the Earth, 23, 159-162.

Jiang, J. K., Hao, J. M., Wu, H., Streets, D. G., Duan, L., \& Tiao, H. Z. (2005). Development of mercury emission inventory from coal combustion in china. Environmental Science, 26, 34-39 (in Chinese).

Landa, E. R. (1978). The retention of metallic mercury vapor by soils. Geochima et Cosmochimica Acta, 42, 1407-1411.

Landis, M., Keeler, G., Al-Wali, K., \& Stevens, R. (2004). Divalent inorganic reactive gaseous mercury emissions from a mercury cell chlor-alkali plant and its impact on near-field atmospheric dry deposition. Atmospheric Environment, 38, 613-622.

Lechler, P. J., Miller, J. R., Hsu, L. C., \& Desilets, M. O. (1997). Mercury mobility at the Carson River Superfund Site, east-central Nevada, USA: Interpretation of mercury speciation data in mill tailings, soils, and sediments. Journal of Geochemical Exploration, 58, 259-267.

Li, C. L. (1992). The reason of high mercury concentration in Beijing soil. Environmental Monitoring in China, 8, 78-80 (in Chinese).

Li, X. X., Lu, A. X., Wang, J. H., Ma, Z. H., \& Zhao, C. J. (2006). Analysis and assessment of soil environmental quality of some farmlands in Beijing. Transaction of Chinese Society of Agricultural Engineering, 22, 60-63 (in Chinese).

Linde, M., Bengtsson, H., \& Öborn, I. (2001). Concentrations and pools of heavy metals in urban soils in Stockholm, Sweden. Water Air and Soil Pollution Focus, 1, 83-101.

Linde, M., Öborn, I., \& Gustafsson, J. P. (2007). Effects of changed soil conditions on the mobility of trace metals in moderately contaminated urban soils. Water Air and Soil Pollution, 183, 69-83.

Liu, J. H., Wang, W. H., \& Peng, A. (1997). Study on mercury species of Beijing surface soils and sediments. Environmental Chemistry, 16, 172-177 (in Chinese).

Liu, J. H., Wang, W. H., \& Peng, A. (1998). Pollution and sources of mercury in top soil in two district of Beijing. Acta Scientiae Circumstantiae, 18, 331-336 (in Chinese).

Liu, S., Nadim, F., Perkins, C., Carley, R. J., Hoag, G. E., Lin, Y., et al. (2002). Atmospheric mercury monitoring survey in Beijing, China. Chemosphere, 48, 97-107.

Mai, B. X., Qi, S. H., Zeng, E. Y., Yang, Q. S., Zhang, G., $\mathrm{Fu}$, J. M., et al. (2003). Distribution of polycyclic aromatic hydrocarbons in the coastal region off Macao, China: Assessment of input sources and transport pathways using compositional analysis. Environmental Science and Technology, 37, 4855-4863.

Mason, R. P., Fitzgerald, W. F., \& Morel, F. M. M. (1994). The biochemical cycling of elementary mercury: Anthropogenic influences. Geochimica et Cosmochimica Acta, 58, 3191-3198.

Moore, J. W., \& Ramamoorthy, S. (1984). Heavy metals in natural waters. New York: Springer. 
Nater, E. A., \& Grigal, D. F. (1992). Regional trends in mercury distribution across the Great Lakes States, North Central USA. Nature, 258, 139-141.

Nriagu, J. O. (1989). A global assessment of natural sources of atmospheric trace metals. Nature, 338, 47-49.

Pacyna, E. G., \& Pacyna, J. M. (2001). Global emissions of mercury from anthropogenic sources in 1995. Water Air and Soil Pollution, 137, 149-165.

Provoost, J., Cornelis, C., \& Swartjes, F. (2006). Comparison of soil clean-up standards for trace elements between countries: Why do they differ? Journal of Soils and Sediments, 6, 173-181.

Reddy, M. M., \& Aiken, G. R. (2001). Fluvic acid sulfide ion competition for mercury ion binding in the Florida Everglades. Water Air and Soil Pollution, 132, 89-104.

Sas-Nowosielska, A., Galimska-Stypa, R., Kucharski, R., Zielonka, U., Małkowski, E., \& Gray, L. (2008). Remediation aspect of microbial changes of plant rhizosphere in mercury contaminated soil. Environmental Monitoring Assessment, 137, 101-109.

Schlúter, K. (2000). Review: Evaporation of mercury from soils, an integration and synthesis of current knowledge. Environmental Geology, 39, 249-271.

Semu, E., \& Singh, B. R. (1987). Absorption of mercury compounds by tropical soils. Water Air and Soil Pollution, 32, 1-10.

Semu, E., Singh, B. R., \& Selmer-Olsen, A. R. (1987). Adsorption of mercury compounds by tropical soils: II. Effects of soil: Solution ration, ionic strength, $\mathrm{pH}$ and organic matter. Water Air and Soil Pollution, 32, $1-10$.

Shuster, E. (1991). The behavior of mercury in the soil with special emphasis on complexation and adsorption process-A review of the literature. Water Air and Soil Pollution, 56, 667-680.

Sznopek, J. L., \& Goonan, T. G. (2000). The materials flow of mercury in the economies of the United States and the world. US Geological Survey Circu- lar 1197. Available from http://greenwoodcr.usgs.gov/ pub/circulars/c1197/.

Tan, M. Z., Chen, J., Zhang, X. L., Chen, J., \& Yan, W. (2005). Pilot study on heavy metal pollution in soils of peri-urban zone of Beijing. Chinese Journal of Soil Science, 36, 96-97 (in Chinese).

Tayban, N., \& Preston, M. R. (2005). Atmospheric vapour phase and particulate phase mercury in a coastal desert climate. Journal of Environmental Monitoring, 7, 997-982.

Trost, P. B., \& Bisque, R. E. (1972). Distribution of mercury in residual soils. In R. Hartung, B. D. Dinman (Ed.), Environmental mercury contamination (pp. 178-196). Ann Arbor, Michigan: Science Publishers.

Wang, Z. W., Zhang, X. S., Zhang, Y., \& Quan, J. N. (2004). Mercury of atmospheric particle $\mathrm{PM}_{2.5}, \mathrm{PM}_{10}$ and snow in Beijing. Environmental Chemistry, 23, 669-673 (in Chinese).

Wright, A. L., Provin, T. L., Hons, F. M., Zuberer, D. A., \& White, R. H. (2005). Dissolved organic C in compost-amended bermudagrass turf. HortScience, 40, 830-835.

Wu, Y. Y., \& Zhou, Q. X. (1991). Interim environmental guidelines for cadmium and mercury in soils of China. Water Air and Soil Pollution, 57-58, 733-743.

Wu, S. H., Zhao, S. Z., \& Liu, X. Y. (1991). Research on the background values of six kinds of trace element in human hair of Beijingese in the southeastern suburbs. Journal of Beijing Polytechnic University, 17, 86-90 (in Chinese).

Zhang, X. M., Luo, K. L., Sun, X. Z., Tan, J. A., \& Lu, Y. L. (2006). Mercury in the topsoil and dust of Beijing City. Science of the Total Environment, 368, 713-722.

Zhu, G. Z. (2001). Pollution of heavy metals on soils in east-south area of Beijing and its remediation. Journal of Agro-environmental Science, 20, 164-166, 182 (in Chinese). 